\title{
THE EFFECT OF FEEDING FREQUENCY ON THE PERFORMANCE PARAMETERS OF THE BROILER BREEDER FLOCKS
}

\author{
Lumturi Sena, Sabah Sena \\ Department of Animal Production, Agricultural University of Tirana, Albania \\ lumturisena@yahoo.com
}

\begin{abstract}
The study was carried out in a broiler breeder flock at the age of $7-23$ weeks. The flock was divided into two groups, which were fed according to two feeding strategies: The control group was fed once a day, while the experimental group was fed once in two days. Both groups were simultaneously monitored for the growth rate (body weight), feed conversion ratio and mortality. At the end of this study, the differences resulted to be significant for the body weight. The control group resulted to have better/heavier body weight ( $3.1 \%$ bigger than the standard). Once a day feeding gives the chicks the possibility for a better performance and efficiency, growing uniformly and meeting an optimal body weight at the age of 23 weeks. Although the control group has consumed $0.6 \%$ more feed/head, the feed conversion ratio (FCR) of this group is $9.5 \%$ higher than the one of the experimental group. This relates and is reflected to a better growth performance for the control group.
\end{abstract}

Key words: broiler breeder pullets; once a day; skip a day; body weight; feed conversion ratio; feed restriction

\section{ВЛИЈАНИЕ НА ФРЕКВЕНЦИЈАТА НА ХРАНЕЊЕ ВРЗ ПАРАМЕТРИТЕ НА ПЕРФОРМАНСИТЕ НА БРОЈЛЕРСКО РОДИТЕЛСКО ЈАТО}

Истражувањето беше спроведено кај јарки од бројлерско родителско јато на 7-23-неделна возраст. Јатото беше поделено во две групи (контролна и експериментална), кои беа хранети на два начина. Контролната група беше хранета еднаш на ден, додека експерименталната група беше хранета еднаш во два дена. И кај двете групи истовремено беа следени стапката на пораст (телесната маса), конверзијата на храна и морталитетот. На крајот од ова истражување добиените разлики беа значајни за телесната маса. Контролната група имаше подобра/поголема телесна маса (3,1\% повисока од стандардната). Хранењето еднаш во денот на пилињата им дава можност за подобри перформанси и ефикасност, рамномерен пораст и добивање оптимална телесна маса на возраст од 23 недели. Иако контролната група потроши $0,6 \%$ храна повеќе по птица, соодносот во конверзијата на храна (FCR) кај оваа група е за 9,5\% повисок од оној кај експерименталната група. Ова се рефлектираше со подобрени перформанси кај птиците од контролната група.

Клучни зборови: бројлерски родителски јарки; еднаш во денот; прескокнат ден; телесна тежина; конверзија на храна; рестрикција на храна

\section{INTRODUCTION}

While breeding stock management, everybody involved in this activity should always remember that the pullets' future performance is primarily determined during the rearing period. Implementation of the controlled growing program is the most critical factor in the life of a breeding stock. Incorrect feed amounts, by mistake or by failure to weigh accurately can lead to overweight or underweight problems which may never be remedied.

Feed quality for the breeding stock should be consistent. Frequent changes in formulation should be avoided. Broiler breeding stock feeding is very different in comparison with the feeding of other categories of poultry. Increase in Txe growth rate through genetic selection and improved nutrition in broiler chickens has been associated with the high body fat deposition (Plavnik et al., 1986; Yu 
and Robinson, 1992). This is particularly evident under ad libitum feeding that is normally practiced ( $\mathrm{Yu}$ and Robinson 1992). Restriction of feed intake by broiler breeders during the growing and laying periods is a common industry practice to prevent excess body weight, which may prove detrimental to reproduction (Zubair A. K. and S. Leeson, 1994). The fact that restriction programs can reduce the body weight and improve feed efficiency, liveability, egg production, fertility and hatchability is documented (Powell T. S. and M. H. Gehle, 1976; Bennett C. D. and S. Lesson, 1989; Bennett C. D. and S. Lesson, 1990; Wilson H. R, D. R. Ingram R. H. Harms, 1983).

Over the years, both qualitative and quantitative feed restriction programs have been proposed to realize these goals (Leeson, Summers, 2000). Through the quantitative feed restriction, in order to keep the body weight under control, a reduction of $15-20 \%$ of the daily amount is practiced, (Zubair A. K., 1994). In parallel with the feed restriction the feeding frequency needs to be planned, if it is going to be once a day, skip a day or skipping one day a week, etc. Skip a day feeding is one of the most commonly used methods of feed restriction during the growing period.

Skip-a-day feeding may be advantageous when feeding space is limited, since it provides feed over a longer period of time and allows timid birds at the lower end of the peck order to feed properly. When skip-a-day feeding is practiced beak trimming may be necessary to prevent picking and injury. This program uses the same feed amounts as the feeding program, but from the start of the week 4-5 through to the end of the week 19-20 feed two days' mash as one feed on one day with scratch feed on the next day, and so on. Through this method of feeding, the pullets will not be able to eat enough feed to meet the needed amount they need for two days; this will lead to a decrease of deposited fat in the organism (Zubair A. K., Leeson S., 1994).

Objective of the study: Improvement of the performance parameters of broiler breeder pullets through a better thought and calculated feed restriction program. To reach this objective, a special feeding program (once a day vs. one day on $\&$ one day off feed) was prepared for the growing pullets and the obtained results were statistically tested.

\section{MATERIALS AND METHODS}

The experiment was performed in a breeding stock in Tirana. The feeding frequency of the broiler breeder pullets was observed for the whole growing period, starting at the week 7 and finishing at the week 23. During the pre-experimental period (0-6 weeks of age) all birds were fed adlibitum. Two groups of 400 females sexed pullets were put in the same management and feeding conditions. The pullets of both groups were fed with the same type/formula of feed and the same daily amount, but while the control group was fed once a day, the experiment group was fed according to the "skip a day" feeding program. According to the respective growing phases, two feed formulas were applied. During the whole growing period, the feed amount was reduced/restricted at a level of $12.3 \%$ compared with the ad-libitum feeding program. With a skip a day program pullets were given these quantities of feed only every other day.

\section{Table 1}

\section{Percentage composition and calculated analysis of experimental diets used for two treatments}

\begin{tabular}{lcc}
\hline \hline Ingredient & $8-14$ weeks & $14-22$ weeks \\
\hline Corn & 65.7 & 64.7 \\
Sun flower meal & 12 & 12 \\
Soy bean meal & 11 & 5 \\
Fish meal & 2 & - \\
Meat \& Bone meal & 2 & 3 \\
Wheat bran & 4 & 11 \\
Micro-ingredients & 1 & 1 \\
Di-calcium phosphate & 1 & 1 \\
Ground limestone & 1 & 2 \\
Iodized salt & 0.3 & 0.3 \\
Total & 100 & 100 \\
\hline Calculated analysis & & \\
\hline M.E. (kcal/kg) & 2748 & 2746 \\
Crude protein & 16.92 & 14.11 \\
Calcium & 1.16 & 1.10 \\
Available phosphorus & 0.50 & 0.44 \\
Methionine & 0.37 & 0.32 \\
Methionine + Cystine & 0.65 & 0.57 \\
Lysine & 0.67 & 0.58 \\
\hline \hline
\end{tabular}


The following parameters were calculated for each group:

1. The body weight of the pullets (every week $5 \%$ of the flock was weighed before the feeding time, while at the beginning of the experiment (week 7) and at the end of it (week 23) the whole flock was weighed.

2. Feed conversion ratio (FCR).

3. Time of the first egg and the laying rate for the first three weeks.

The whole set of data was through ANOVA and Descriptive Analysis tested. The statistical analysis of the data was carried out by the student's $t$-test.

\section{RESULTS AND DISCUSSION}

\section{Body weight}

The body weight records, statistically calculated are displayed in the Table 2.
At the age of 7-16 weeks, both groups have reached an over standard body weight. It means that if the feed restriction had been started at an earlier stage and the restriction level had been at a higher level, both groups would have been within the standard body weight.

Until the end of the growing period, the body weight of the control group has been higher than the one of the experimental group and the standard of the line. Anyhow, the differences between the two groups are significant after the age of 18 weeks only, which means that the effect of feeding frequency was reflected after this age only. The body weight at the $23^{\mathrm{d}}$ week is in fact the one of a matured pullet, while at this age the growing period is finished. Considering this fact, it is of both practical and scientific value for this research, because it is associated with the maturity of the pullets, reaching the sexual maturity and reproductive capabilities. At the $23^{\mathrm{d}}$ week the body weight differences between the two groups are significant (for the $\mathrm{P} \geq 0.01$ ).

Table 2

Body weights of pullets from 7-23 week of age

\begin{tabular}{ccccc}
\hline \hline Week & \multicolumn{2}{c}{ Experiment } & $T_{\text {stat }}$ & Standard \\
\cline { 2 - 4 } & Control group & Experiment group & & \\
\hline 7. & $882.50 \pm 17.16$ & $877.50 \pm 19.14$ & 0.210 & 750 \\
8. & $988.00 \pm 25.59$ & $977.00 \pm 26.00$ & 0.301 & 850 \\
9. & $1101.25 \pm 33.43$ & $1082.75 \pm 23.44$ & 0.453 & 950 \\
10. & $1208.50 \pm 42.65$ & $1148.00 \pm 33.53$ & 0.562 & 1050 \\
11. & $1319.70 \pm 20.47$ & $1271.75 \pm 35.75$ & 1.165 & 1150 \\
12. & $1417.00 \pm 38.97$ & $1362.75 \pm 36.21$ & 1.020 & 1250 \\
13. & $1516.50 \pm 55.58$ & $1448.25 \pm 46.08$ & 0.917 & 1350 \\
14. & $1613.00 \pm 73.92$ & $1527.75 \pm 59.33$ & 1.018 & 1450 \\
15. & $1709.75 \pm 56.98$ & $1603.75 \pm 40.05$ & 1.096 & 1550 \\
16. & $1805.00 \pm 46.16$ & $1677.50 \pm 40.67$ & 2.072 & 1650 \\
17. & $1897.50 \pm 58.58$ & $1750.50 \pm 39.99$ & 2.051 & 1750 \\
18. & $1987.50 \pm 73.16$ & $1822.50 \pm 34.60$ & 2.042 & 1850 \\
19. & $2077.50 \pm 55.25$ & $1892.50 \pm 55.04$ & +2.370 & 1950 \\
20. & $2162.50 \pm 53.51$ & $1960.00 \pm 60.64$ & +2.504 & 2050 \\
21. & $2247.50 \pm 61.53$ & $2030.00 \pm 59.20$ & +2.547 & 2150 \\
22. & $2329.50 \pm 61.56$ & $2090.00 \pm 38.77$ & +++3.292 & 2250 \\
23. & $2397.72 \pm 18.01$ & $2148.05 \pm 17.36$ & +++9.983 & 2350 \\
\hline \hline
\end{tabular}


Considering the above mentioned results, it might be concluded that the pullets' body weight of the control group at $23^{\mathrm{d}}$ weeks of age, restrictively fed according to the "once a day" approach, fits better within the body weight range of the pullets of the breeding flocks.

A slight supremacy in the body weight gain of pullets from the control group relates with the feeding frequency. Feeding the whole daily amount of feed in the morning, it will be possible for the pullets to eat all of it, ensuring a better uniformity in growth, but at the same time avoiding, the stress of a relative lower amount of feed, which in this case is done on purpose and will have a positive effect.

Mc Daniel G. R, (1986), Wilson H. R., et al. (1989), have studied the superiority of once a day feeding through studying the performance parameters of the pullets. Birds will utilise their feed 10 $15 \%$ more efficiently when fed every day rather than skip a day. When fed skip a day, the bird must store nutrients (body fat and some body protein) which must be utilised by the bird for the growth and maintained for the following day when it has no access to feed. Unfortunately this deposition and re-utilization of nutrients is not $100 \%$ (S. Leeson and J. D. Summers, 2000).

\section{Feed conversion ratio}

The feed conversion for both groups follows in general a biological regularity. At the beginning of the experiment, since the growing dynamics is high, the feed conversion rate is better, but later on, a tendency of a lower growth and feed conversion rate can be seen. The superiority of the control group for the Feed Conversion Rate (FCR) can start coming to the evidence at the week 10 until the end of the growing period. The pullets of this group have consumed $9.5 \%$ less feed $/ \mathrm{kg}$ of the body weight gain.

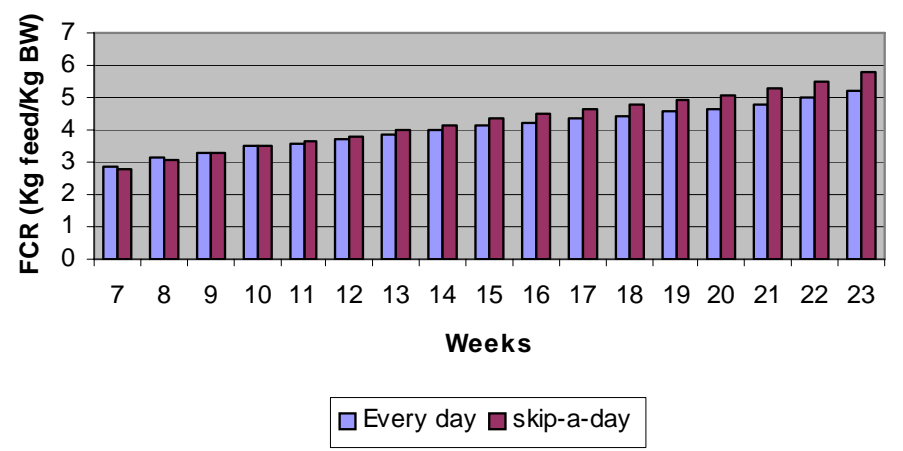

Figure 1: Feed conversion ratio during rearing period ( $\mathrm{kg}$ feed $/ \mathrm{kg}$ body weight)

The "once a day" feeding approach, brought up a better feed digestion/metabolism and consequently has a better growth rate/gain from the pullets. The improvement in feed efficiency through feed restriction has been attributed in part to higher metabolic efficiency associated with maintenance a smaller body and a lower metabolic rate during the early growth (Dickerson, 1978).

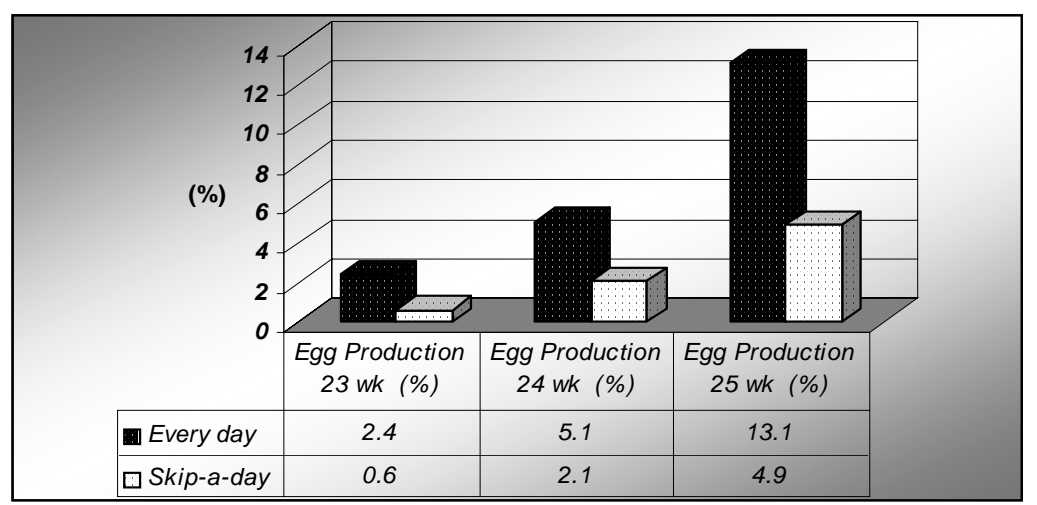

Figure 2: Effect of feeding frequency on early breeder performance 


\section{Age at maturity}

Although the sexual maturity age/time of both groups is the same, (the first egg was laid at 149 days), the same thing can't be stated for the laying/egg production rate of both groups during the first three weeks of the production period. Since the first week of lying, the superiority of the control group can easily be seen. Anyhow the above mentioned data can't be considered enough to judge the egg production process in a later period when the pullets will become under the "laying hens" category. Underweight birds at sexual maturity most often show a characteristic loss in production, especially at a beginning of egg laying (S. Leeson and J. D. Summers, 2000; Fatori T., H. R. Wilson et al., 1993).

\section{CONCLUSIONS}

Results taken from this study, where the pullets are fed with identical quantities of feed, indicated that the "once a day" feeding approach is more efficient than the "skip a day" one. In this study, all pullets were matured at the same time (time of the first egg), but had vastly different body weight.

\section{REFERENCES}

[1] Bennett, C. D and S. Lesson (1989): Growth of broiler breeder pullets with skips a day vs. daily feeding. Poult. Sci. 68: 836-838.

[2] Bennett, C. D., S. Lesson, H. S. Bayley (1990): Heat production of skip a day and daily feed broiler breeder pullets. Can. J. Anim. Sci. 70: 767-775.

[3] Dickerson G. E. (1978): Animal size and efficiency: basic concepts. Anim. Prod. 27: 367-379.

[4] Fatori T. R, H. R Wilson et al. (1993): Response of broiler breeder females to feed restriction bellow recommended levels. 3. Characterizing the onset the sexual maturity. Poult. Sci. 72: 2044-2051.

[5] Leeson S., J. D. Summers (2000): Broiler breeder production. $148-158$.

[6] Plavnik I., J. P. Mc Murtry and R. W. Rosebrough (1986): Effect of early feed restriction in broilers. Growth performance and carcass composition. Growth, 50: 68-76.

[7] Powell, T. S. and M. H Gehle (1976). Effect of various pullet restriction methods on performance of broiler breeders. Poult. Sci. 55: 502-509.

[8] Wilson H. R., D. R. Ingram, F. B Mather, R. H Harms (1989): Effect of daily restriction and age of initiation of a skip a day program for young broiler breeders. Poult. Sci. 68: 1442-1446.

[9] Wilson H. R., D. R. Ingram, R. H Harms (1983): Restricted feeding of broiler breeders. Poult. Sci. 62: 11331141

[10] Yu, M. W., F. E. Robinson and A. R. Robble (1992): Effect of feed allowance during a rearing and breeding on female broiler breeders. Poult. Sci. 71: 1739-1749.

[11] Zubair A. K. and S. Leeson (1994): Effect of early feed restriction and re-alimentation on heat production and changes in sizes of digestive organs of male broilers. Poult. Sci. 73: 529-539. 